\title{
Eksplorasi dan identifikasi pisang apuy sebagai kultivar unggul lokal kabupaten Majalengka
}

\author{
Acep Atma Wijaya ${ }^{1)}$ \\ ${ }^{1}$ Program Studi Agroteknologi, Fakultas Pertanian Universitas Majalengka \\ Jln. K. H. Abdul Halim, No. 103 Majalengka \\ Email: acepatma.w@unma.ac.id
}

Exploration and Identification of apuy bananas as local superior cultivars in Majalengka Regency

Informasi artikel:

Dikirim: 01/03/2020

ditinjau: 02/03/2020

disetujui: 30/03/2020

Copyright (c) 2020 Acep Atma Wijaya

\begin{abstract}
The development of local cultivars is one of the activities that must be carried out in promoting their respective regions. Majalengka Regency is a developing Regency so there is a need for a commodity that characterizes the area. One commodity that can be developed for tourist attraction is the local apuy Banana. The existence of apuy bananas is increasingly pushed every year due to the presence of other superior banana cultivars, besides that the public's knowledge of the characteristics of apuy's local bananas is still very diverse so it needs information about the characteristics of local apuy bananas, so that the community can be uniform. The purpose of this study is to explore and identify local apuy bananas as superior banana ingredients in Majalengka Regency. This study uses a census method of local apuy cultivars, pisang Raja Dakit and pisang Raja Lemongrass. The results showed there was diversity between apuy Local Bananas, raja dengkel Bananas and raja sereh Bananas in terms of Morphological characters. Based on the results of relationship analysis, the level of similarity between genotypes observed was in the range of 77 to 92,51.
\end{abstract}

Keywords: apuy bananas, Majalengka cultivars, relationship analysis

ABSTRAK: Pengembangan kultivar lokal merupakan salah satu kegiatan yang harus dilakukan dalam mempromosikan daerah masing-masing. Kabupaten Majalengka merupakan Kabupaten yang sedang berkembang sehingga perlu adanya suatu komoditas yang mencirikan daerah tersebut. Salah satu komoditas yang dapat dikembangkan untuk daya tarik wisatawan adalah pisang lokal apuy. Keberadaan pisang apuy setiap tahunnya semakin terdesak akibat keberadaan kultivar pisang unggul lainnya, selain itu pengetahuan masyarakat terhadap ciri-ciri pisang lokal apuy masih sangat beragam sehingga perlu informasi mengenai ciri-ciri pisang lokal apuy, sehingga di masyarakat bisa seragam. Tujuan dari penelitian ini adalah mengeksplorasi dan Identifikasi pisang lokal apuy sebagai bahan pisang unggulan Kabupaten Majalengka. Penelitian ini menggunakan metode sensus terhadap kultivar lokal apuy, pisang raja dengkel dan pisang Raja Sereh. Hasil penelitian menunjukkan terdapat keragaman antara pisang Lokal apuy, raja dengkel dan raja sereh dilihat dari karakter Morfologi. Berdasarkan hasil analisis kekerabatan, tingkat kesamaan antara genotip yang diamati berada pada rentang 77 sampai 92,51.

Kata Kunci: kabupaten Majalengka, pisang apuy, uji kekerabatan

Sitasi: Wijaya, A. A. (2020). Identifikasi pisang apuy sebagai kultivar unggul lokal kabupaten Majalengka. AGROMIX, 11(1),79-86. https://doi.org/10.35891/agx.v11i1.1907

\section{PENDAHULUAN}

Tanaman pisang termasuk ke dalam tanaman hortikultura unggulan di Indonesia, dan merupakan tanaman buah yang banyak manfaat (Kumar dkk., 2012; Singh dkk., 2016;
Wambugu \& Kiome, 2001). Buah pisang dapat dimakan langsung sebagai buah meja atau dapat menjadi bahan baku olahan produk pisang (Aurore dkk., 2009; Padam dkk., 2014; Rahman dkk., 2011). Buah pisang kaya akan 
gizi, hasil penelitian Hardisson dkk. (2001) menunjukkan bahwa buah pisang banyak mengandung Kalsium (Ca), Lemak 23,93\%, Protein 5,53\%, Karbohidrat 32,39\%, Serat 14,83\%, Kalsium 4113,72 mg, Vitamin A 75-950 SI, dan Vitamin C 2-10 mg. Selain kaya akan kandungan gizi, pisang juga bermanfaat untuk proses pengobatan tradisional. Hasil penelitian Imam dan Akter (2011) pisang dapat digunakan sebagai pengobatan tradisional untuk berbagai penyakit di antaranya Disentri, Diabetes, Hipertensi, penyakit jantung, mencret, dan untuk pengobatan luka.

Jawa Barat merupakan propinsi sentral produksi pisang terbesar ketiga di Indonesia setelah Lampung dan Jawa Timur. Produksi pisang Jawa Barat pada Triwulan II tahun 2015 sebesar 299.113 ton, jumlah tersebut lebih rendah dibandingkan dengan produksi Triwulan I tahun 2015 yaitu sebesar 360.082 ton. Secara nasional, kontribusi produksi pisang pulau Jawa pada periode $2011-2015$ (54,07\%) menurun dibandingkan pada periode 19802010 (61,91\%). Hal berbeda terjadi pada produksi di luar pulau Jawa, kontribusi produksi justru meningkat dari 38,09\% periode tahun 1980-2010 menjadi 45,93\% pada periode tahun 2011-2015 (Rohmah, 2016).

Kabupaten Majalengka merupakan kabupaten di propinsi Jawa Barat yang menyimpan banyak sumber daya genetik tanaman lokal yang berpotensi sebagai kultivar unggul. Pesatnya pembangunan dengan hadirnya banda- ra Internasional Kertajati membuat semakin terdesaknya penyebaran tanaman lokal, sehingga semakin sedikit jenis tanaman lokal yang masih tumbuh. Selain itu, penanaman kultivar unggul yang disarankan pemerintah membuat petani semakin tidak tertarik untuk penanaman kultivar lokal (Sumarno dkk., 2018).

Pisang apuy merupakan kultivar pisang lokal asal Majalengka yang saat ini keberadaannya semakin berkurang (Iman, 2019; Wijaya dkk., 2019). Populasi pisang apuy setiap tahun semakin berkurang akibat petani lebih tertarik untuk menanam kultivar pisang lain yang dapat berproduksi lebih tinggi dibandingkan pisang apuy. Apabila permasalahan tersebut dibiarkan, tidak menutup kemungkinan populasi pisang apuy akan hilang dan hanya tinggal cerita, sehingga diperlukan dilakukan langkah nyata yaitu dengan mengidentifikasi dan konservasi terhadap pisang apuy. Hasil penelitian Simangunsong dkk. (2017) di kabupaten Nganjuk, Mojokerto, Lumajang dan Kediri. Hasil penelitiannya menunjukkan terdapat 8 jenis pisang mas yang tersebar di empat kabupaten tersebut yaitu, pisang mas kirana, mas keripik, mas talun, mas Sumatra, mas biasa, mas mirah, mas jiranan, dan mas obat.

Plasma nutfah pisang apuy merupakan bahan tanaman yang sangat berharga sebagai bahan pemuliaan tanaman. Kelebihan pisang apuy berada pada rasa dan aroma buah pisa- 
ngnya. Rasa manis dan renyah serta wangi yang khas membuat pisang apuy dapat dijadikan sebagai kukltivar unggul ataupun sebagai tetua persilangan untuk merakit kultivar pisang yang memiliki aroma yang khas.

Program pemuliaan tanaman pisang telah menjadi perhatian dunia. Oleh sebab itu pengembangan tanaman pisang sangat potensial untuk dikembangkan dalam kegiatan pemuliaan tanaman. Strategi pengembangan dan konservasi tanaman pisang menjadi perhatian dunia. MusaNet dan Laliberte (2016) menyebutkan terdapat lima strategi dalam pengembangan dan konservasi sumber daya genetik tanaman pisang dunia yaitu (1) pengujian keragaman genetik pisang dan mengidentifikasi kebenaran gaps dalam keragaman, (2) konservasi gen pool pisang secara in situ, ex situ dan secara onfarm, (3) maksimalisasi penggunaan keragaman genetik melalui karakterisasi secara komprehensif pada aksesi untuk dievaluasi, (4) pemanfaatan analisis genomic dalam pemuliaan tanaman pisang, (5) kemudahan akses dalam mendapatkan informasi dan pemanfaatan plasma nutfah.

Tujuan dari penelitian ini adalah untuk mengeksplorasi dan identifikasi populasi pisang apuy yang masih tersedia untuk bahan program pemuliaan tanaman. Dengan tersedianya data mengenai karakter pisang apuy hasil penelitian diharapkan pemahaman masyarakat kabupaten Majalengka dapat diseragamkan tentang pisang apuy.

\section{METODE PENELITIAN}

Penelitian ini dilaksanakan pada Bulan Maret 2019 sampai Oktober 2019. Penelitian dilakukan di empat desa yaitu desa Teja, Argamukti, Cikaracak dan Argalingga. Keempat desa tersebut merupakan desa tempat penyebaran pisang apuy.

Bahan yang digunakan dalam penelitian ini adalah populasi pisang apuy sebagai sample dan populasi pisang raja sereh dan raja dengkel sebagai pembanding. Penelitian ini menggunakan metode sensus di mana setiap tanaman pisang apuy, pisang raja dengkel dan raja sereh yang tumbuh di empat desa tersebut serta petani yang membudidayakan dijadikan sample penelitian. Penggunaan metode ini dikarenakan sample dari ketiga jenis tanaman tersebut kurang dari 100 populasi. Menurut Arikunto (2012) jika populasi sample kurang dari 100 maka yang menjadi sample adalah seluruh populasi, sedangkan jika lebih dari 100 sample maka $10-15 \%$ atau $20-25 \%$. Petani yang membudidayakan ketiga jenis pisang tersebut dijadikan sebagai bagian dari penelitian ini untuk mengetahui tingkat sosial ekonomi petani tersebut. Karakter-karakter yang diamati pada ketiga jenis pisang tersebut adalah semua karakter yang termasuk ke dalam descriptor pisang yang dikeluarkan oleh IPGRI.

Analisis data hasil pengamatan diuji berdasarkan uji kekerabatan. Uji kekerabatan dilakukan untuk mengetahui kedekatan hubungan kekerabatan antara pisang apuy dengan 
pisang raja sereh dan raja dengkel. Analisis data menggunakan perangkat lunak SPSS versi 21.

\section{HASIL DAN PEMBAHASAN}

Kegiatan karakterisasi dilakukan untuk mengetahui karakter morfologis dari suatu tanaman (Nedha dkk., 2018) yang selanjutnya dapat dijadikan sebagai dasar penentuan keragaman yang terjadi pada individu tersebut. Karakterisasi dapat dilakukan pada karakter kualitatif maupun karakter kuantitatif, hanya saja kelihatan karakterisasi akan lebih mudah dilakukan pada karakter-karakter kualitatif. Hal ini dikarenakan karakter kualitatif lebih sedikit dipengaruhi oleh faktor lingkungan.

Kegiatan karakterisasi pisang apuy dilakukan di tiga lokasi yang terdapat individuindividu pisang apuy. Ketiga lokasi tersebut
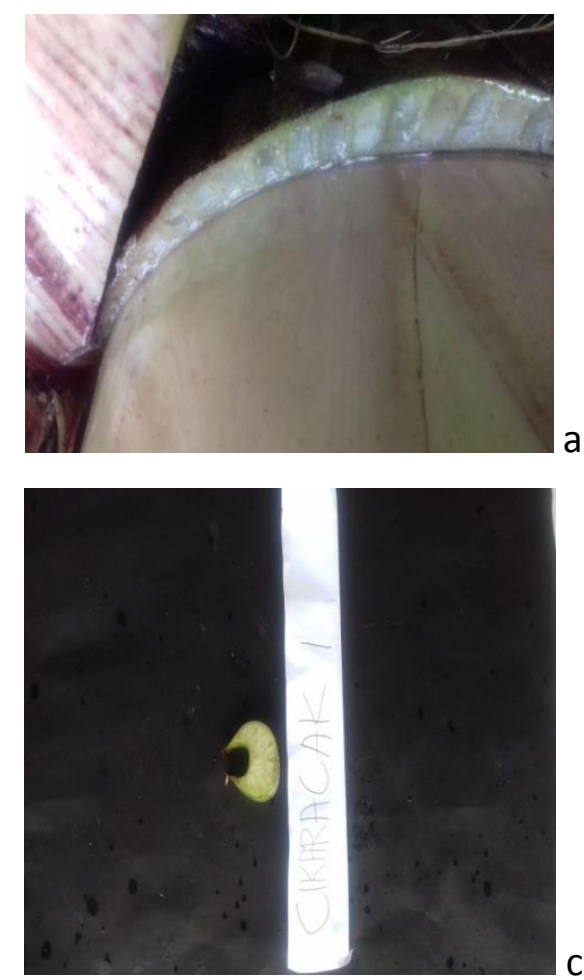

adalah Argamukti, Cikaracak, dan Argalingga. Ketiga lokasi tersebut berada dalam kawasan Taman Nasional Gunung Ciremai (TNGC), berada pada ketinggian 1200 meter diatas pemukaan laut (mdpl). Terdapat 8 aksesi pisang apuy yang memiliki penampilan yang berbeda hasil eksplorasi dari ketiga desa tersebut. Hasil penelitian Hamarawati dkk. (2009) menunjukkan bahwa keberagaman tanaman pisang pada suatu lokasi/ wilayah tertentu disebabkan oleh cocok atau tidaknya lokasi/ wilayah tersebut sebagai tempat tumbuh tanaman pisang tersebut. Untuk mengetahui tingkat kekerabatan antara aksesi-aksesi pisang lokal apuy, pisang raja dengkel dan pisang raja sereh maka harus diuji kekerabatan. Perbedaan tiap aksesi pisang dapat dilihat pada Gambar 1.
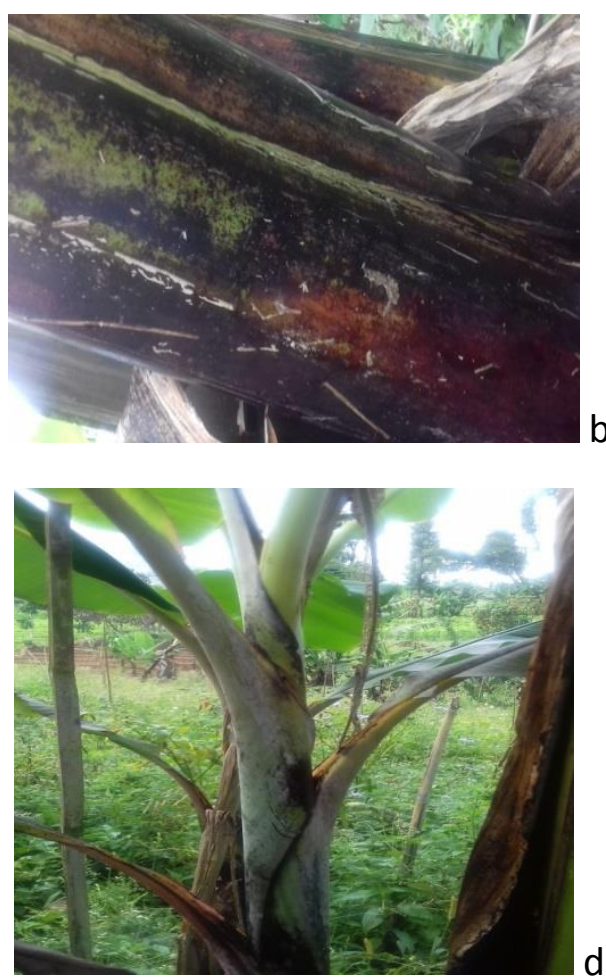

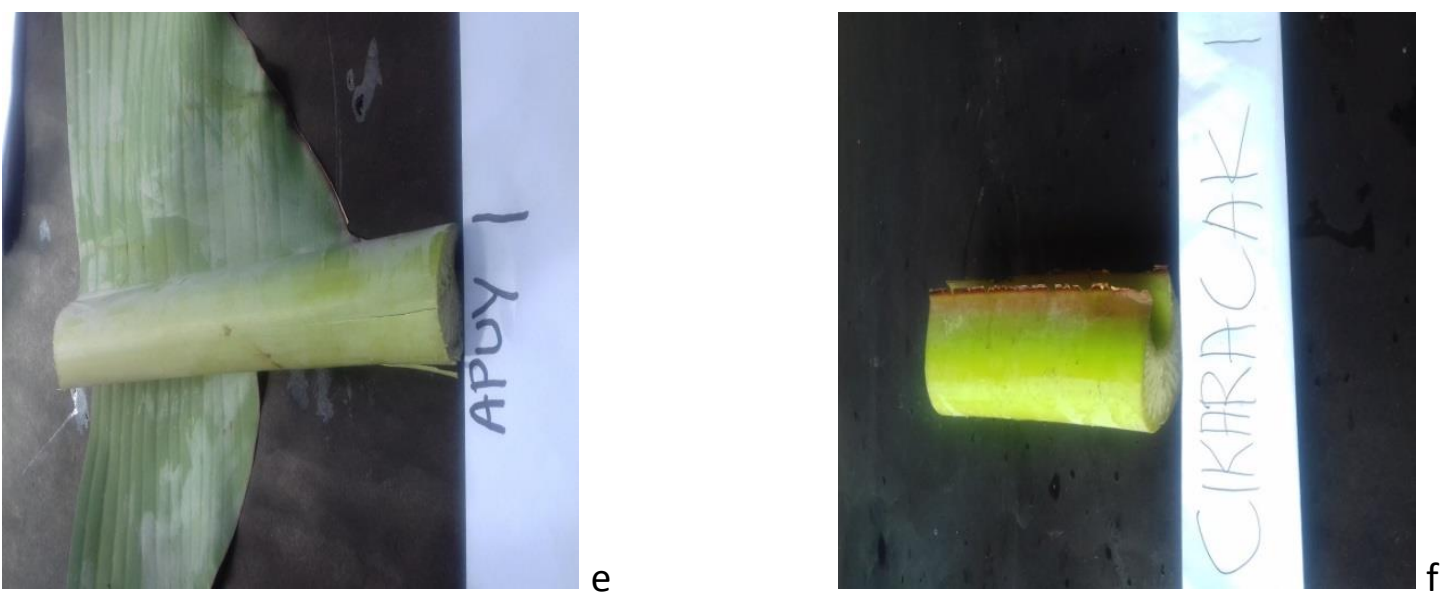

Gambar 1. Perbedaan tiap aksesi pisang apuy

Keterangan: $a$ = warna dasar batang; $b=$ Tampilan batang; $c=$ saluran tangkai daun ke 3; $d=$ bentuk daun; $e=$ bentuk dasar pangkal daun; $f$ = warna permukaan pelepah

Hasil analisis tingkat kekerabatan antara pisang apuy, raja dengkel dan raja sereh digambarkan dalam bentuk dendogram (Gambar 2). Berdasarkan dendogram (Gambar 2) terlihat bahwa terdapat 4kluster yang memperlihatkan kekerabatan antara sample pisang apuy, raja dengkel dan Raja Sereh. Berdasarkan analisis, tingkat kesamaan antara 24 sample dari ketiga jenis pisang tersebut terbagi ke da- lam beberapa kelompok. Pada tingkat kesamaan 92,51 terbagi ke dalam 16 kelompok, pada tingkat kesamaan 85,03 terdiri dari 9 kelompok, dan tingkat skala 77,54 terdiri dari 4 kelompok. Hasil ini sesuai dengan penelitian Aryanti dkk. (2015) menjelaskan bahwa semakin kecil nilai kesamaan antara individu yang diamati maka semakin kecil tingkat kekerabatannya.

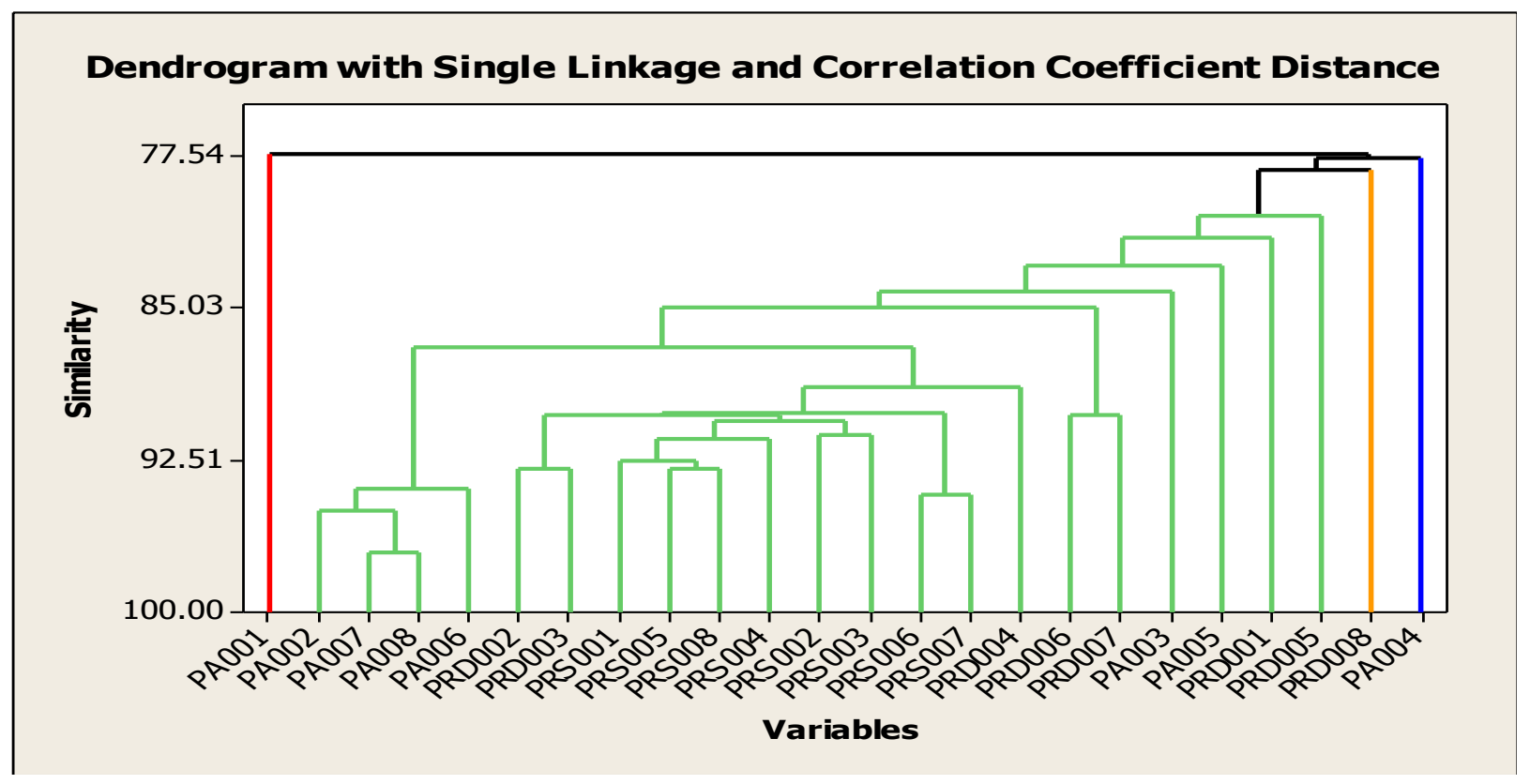

Gambar 2. Dendogram hubungan kekerabatan pisang apuy, raja sereh, dan raja dengkel Keterangan: PA (Pisang apuy), PRD (Pisang raja dengkel, PRS (Pisang Raja Sereh) 
Tingkat kesamaan pada level 92,51 terdiri dari 16 kelompok yang memiliki kekerabatan yang dekat yaitu kelompok 1 (PA001), kelompok 2 (PA002,PA007,PA008, PA006) kelompok 3 (PRD002 dan PRD003), kelompok 4 (PRS001), kelompok 5 (PRS005, PRS008), kelompok 6 (PRS004), kelompok 7 (PRS002, PRS003), kelompok 8 (PRS006, PRS007), kelompok 9 (PRD004), kelompok 10 (PRD006, PRD007), kelompok 11 (PA003), kelompok 12 (PA005), kelompok 13 (PRD001), kelompok 14 (PRD005), kelompok 15 (PRD008), dan kelompok 16 (PA004).

Level kesamaan 85,03 terdiri dari 9 kelompok. Sample yang masuk ke dalam 9 kelompok tersebut yaitu kelompok 1 (PA001), kelompok 2 (PA002, PA007, PA008, PA006, PRD002, PRD003, PRS001, PRS005, PRS008, PRS004, PRS002, PRS003, PRS006, PRS007, PRD004), kelompok 3 (PRD006, PRD007), kelompok 4 (PA003), kelompok 5 (PA005), kelompok 6 (PRD001), kelompok 7 (PRD005), kelompok 8 (PRD008), dan kelompok 9 (PA004).

Level kesamaan pada tingkat 77,54 terdiri dari 4 kelompok yaitu kelompok 1 (PA001), kelompok 2 (PA002, PA007, PA008, PA006, PRD002, PRD003, PRS001, PRS005, PRS008, PRS004, PRS002, PRS003, PRS006, PRS007, PRD004, PRD006, PRD007, PA003, PA005, PRD001, PRD005) kelompok 3 (PRD008), dan kelompok 4 (PA004).

Hasil pengelompokan tersebut dapat dilihat bahwa walaupun pisang satu jenis pi- sang tetapi dilihat dari jarak kesamaannya dapat saja berjarak jauh. Hal ini mungkin disebabkan oleh perbedaan lingkungan yang menjadi tempat tumbuhnya. Irawan dan Purbayanti (2008) menyatakan bahwa jika suatu kultivar yang sama berasal dari daerah yang sama jika lingkungan tempat tumbuhnya berbeda maka akan mempengaruhi diversitas genetic sehingga tidak selalu dalam satu kelompok yang sama kedekatan hubungan kekerabatan dicirikan dengan banyaknya persamaan karakter antara tanaman satu dengan tanaman lain (Aryanti dkk., 2015). Pemanfaatan karakter morfologi sebagai dasar menentukan nilai kedekatan suatu genotip merupakan hal yang sangat mudah dilaksanakan akan tetapi nilai keefektifannya masih harus diperhatikan. Hal ini disebabkan karena karakter morfologi sangat dipengaruhi oleh lingkungan. Hasil penelitian Simmond (1955) menunjukkan bahwa walaupun suatu genotip memiliki konstitusi genom yang sama AAA tetapi hasil analisis menunjukkan genotip tersebut berada pada kluster yang berbeda, Buxton \& Fales, (1994) menyatakan bahwa karakter morfologi sangat dipengaruhi oleh lingkungan.

Tingkat kesamaan pada penelitian ini antara 77 sampai 95. Hal ini menunjukkan ketiga jenis pisang ini memiliki tingkat kedekatan yang tinggi. Hal ini diduga selain dari tingkat genom yang sama, pedigree dari ketiga jenis pisang ini hampir berkerabat dekat. Hasil penelitian Abdullah dkk. (2012) yang memperlihatkan bahwa 
pisang dengan genom yang sama memperlihatkan tingkat kesamaan lebih tinggi dibandingkan dengan pisang dengan tingkat genom yang berbeda.

\section{KESIMPULAN}

Berdasarkan hasil pengamatan, maka dapat diambil kesimpulan terdapat keragaman antara pisang Lokal apuy, raja dengkel dan raja sereh dilihat dari karakter Morfologi. Berdasarkan hasil analisis kekerabatan, tingkat kesamaan antara genotip yang diamati berada pada rentang 77 sampai 92,51. Terdapat 8 jenis pisang apuy hasil eksplorasi di tiga desa dengan karakter morfologi berbeda.

\section{UCAPAN TERIMAKASIH}

Terima kasih yang sebesar-besarnya penulis sampaikan kepada Kemenristek DIKTI yang telah memberikan bantuan dana penelitian melalui skema Hibah Penelitian Dosen Pemula (PDP) Tahun Anggaran 2019.

\section{DAFTAR PUSTAKA}

Abdullah, B. J., Nasreen, R., \& Ravichandran, N. (2012). A comprehensive review of consumption pattern and strategies in cosmeceutical market with a focus on dermaceuticals in Indian market. International Journal of Scientific and Research Publications, 2(2), 176-179.

Arikunto, S. (2012). Produser penelitian suatu pendekatan praktek. Jakarta: PT. Rineka Cipta.

Aryanti, I., Bayu, E. S., \& Kardhinata, E. H. (2015). Identifikasi karakteristik morfologis dan hubungan kekerabatan pada tanaman jahe (Zingiber officinale Rosc.) di Desa Dolok Saribu Kabupaten Simalungun. Jurnal Online Agroekoteknologi, 3(3), 963-975.

Aurore, G., Parfait, B., \& Fahrasmane, L. (2009). Bananas, raw materials for making processed food products. Trends in Food Science \& Technology, 20(2), 78-91. https://doi.org/10.1016/j.tifs.2008.10.0 03

Buxton, D. R., \& Fales, S. L. (1994). Plant environment and quality. Forage quality, evaluation, and utilization, 155-199.

Hamarawati, E., Mugiastuti, E., Manan, A., Loekito, S., Soesanto, L., Banati, R., Mahajoeno, F., Kosiyachinda, S., Jumjunidang, R., \& Emilda, D. (2009). Systemic acquired resistance and induced systemic resistance in conventional agriculture. Asian Journal of Plant Pathology, 12(1), 131-137.

Hardisson, A., Rubio, C., Baez, A., Martin, M., Alvarez, R., \& Diaz, E. (2001). Mineral composition of the banana (Musa acuminata) from the island of Tenerife. Food Chemistry, 73(2), 153-161. https://doi.org/10.1016/S03088146(00)00252-1

Imam, M. Z., \& Akter, S. (2011). Musa paradisiaca L. and Musa sapientum L.: A phytochemical and pharmacological review. Journal of Applied Pharmaceutical Science, 1(5), 14-20.

Iman, A. S. N. (2019). Karakterisasi morfologi pisang apuy (Musa X Sapientum L.) di Desa Argamukti Kabupaten Majalengka [PhD Thesis]. UIN Sunan Gunung Djati Bandung.

Irawan, B., \& Purbayanti, K. (2008). Karakterisasi dan kekerabatan kultivar padi lokal di desa Rancakalong, Kecamatan Rancakalong, Kabupaten Sumedang. Bandung (ID): Makalah dipresentasikan pada Seminar Nasional PTTI pada tanggal, 21-23.

Kumar, K. S., Bhowmik, D., Duraivel, S., \& Umadevi, M. (2012). Traditional and medicinal uses of banana. Journal of 
Pharmacognosy and Phytochemistry, 1(3), 51-63.

MusaNet, \& Laliberte, B. (2016). Global strategy for the conservation and use of Musa genetic resources. Bioversity International.

https://cgspace.cgiar.org/handle/10568 $/ 77332$

Nedha, N., Purnamaningsih, S. L., \& Damanhuri, D. (2018). Observasi dan karakterisasi morfologi tanaman pisang (Musa spp.) di kecamatan Ngancar kabupaten Kediri. Jurnal Produksi Tanaman, 5(5), 821827.

Padam, B. S., Tin, H. S., Chye, F. Y., \& Abdullah, M. I. (2014). Banana by-products: An under-utilized renewable food biomass with great potential. Journal of Food Science and Technology, 51(12), 35273545. https://doi.org/10.1007/s13197012-0861-2

Rahman, T., Luthfiyanti, R., \& Ekafitri, R. (2011). Optimasi proses pembuatan food bar berbasis pisang. Prosiding SNaPP2011 Sains, Teknologi, dan Kesehatan, 2(1), 295-302.

Rohmah, Y. (2016). Outlook komoditas pertanian sub sector hortikultura (pisang). Pusat Data dan Sistem Informasi Pertanian, Kementrian Pertanian.

Simangunsong, A. D., Respatijarti, R., \& Damanhuri, D. (2017). Eksplorasi dan karakterisasi pisang mas (Musa Spp) di kabupaten Nganjuk, Mojokerto, Lumajang dan Kediri. Jurnal Produksi Tanaman, 5(3), 363-367.

Simmonds, N. W., \& Shepherd, K. (1955). The taxonomy and origins of the cultivated bananas. Botanical Journal of the Linnean Society, 55(359), 302-312. https://doi.org/10.1111/j.1095-

8339.1955.tb00015.x

Singh, B., Singh, J. P., Kaur, A., \& Singh, N. (2016). Bioactive compounds in banana and their associated health benefits $-A$ review. Food Chemistry, 206, 1-11. https://doi.org/10.1016/j.foodchem.20 16.03.033
Sumarno, nFN, Pusat Penelitian dan Pengembangan Tanaman Pangan, B., Zuraida, N., \& Balai Besar Penelitian dan Pengembangan Bioteknologi dan Sumber daya Genetik Pertanian, B. (2018). Pengelolaan plasma nutfah tanaman terintegrasi dengan program pemuliaan [Penelitian]. Balai Besar Penelitian dan Pengembangan Bioteknologi dan Sumber daya Genetik Pertanian. http://repository.pertanian.go.id/handl e/123456789/2062

Wambugu, F. M., \& Kiome, R. M. (2001). The benefits of biotechnology for small-scale banana producers in Kenya. ISAAA.

Wijaya, A. A., Jaja, J., Nugraha, D. R., \& Rahmah, U. I. L. (2019). Uji hedonik pisang lokal apuy sebagai bahan kultivar unggul lokal kabupaten Majalengka. Agrivet : Jurnal Ilmu-IImu Pertanian dan Peternakan (Journal of Agricultural Sciences and Veteriner), 7(1), 83-88. 